\title{
The international clusters in the innovative development of an energy efficient economy
}

\author{
Inga Skvortsova ${ }^{1}$, Roman Latyshev ${ }^{1, *}$, and Kirill Grabovyy ${ }^{2}$ \\ ${ }^{1}$ Peter the Great Saint-Petersburg Polytechnic University, 29 Polytechnicheskaya, Saint-Petersburg, \\ 195251, Russia \\ ${ }^{2}$ Moscow State University of Civil Engineering, 129337, 26, Yaroslavskoe Shosse, Moscow, Russia
}

\begin{abstract}
The purpose of this article is to analyze the current level of innovation activity in the Russian Federation, to determine the role of international clusters in the innovative development of the energy efficient country's economy, while focusing on the formation of the innovative potential of international cooperation of cluster members. The urgency of the creation of cluster associations - international consortia. Examples of the joint implementation of innovative projects in the field of energyefficient management and the application of new technologies in the field of sustainable energy for megacities are given.
\end{abstract}

\section{Introduction}

Today, innovations are an extremely important link in all spheres of life in a developed society. It is already hard to imagine modern life without innovations that have already been realized and become habitual, and without future ones that contribute to the further prosperity of society. Innovations, and in particular the products of commercialization of research and development, are the engine of economic growth of many countries, as well as the basis for industrial, scientific, technological and social development. The goal of the development strategy of many states is to move away from the "raw material economy" to the "innovative" economy.

\subsection{Analysis of the current level of innovation activity in the Russian Federation}

Unfortunately, at the moment, the actual level of innovation activity of enterprises in the Russian Federation is very low. Rosstat data shows that the proportion of organizations that have implemented technological innovations in the industry in 2014-2017 slightly exceeded $9 \%$, which is $1 \%$ lower than in the period from 2010-2013. [1]. The total level of innovation activity, which includes both technical and managerial innovations in these years, was $10.7 \%$. If we compare the level of innovation activity in the Russian Federation with the activity level of enterprises in other countries, we will get a sad result - an indicator of activity in the Russian Federation is significantly lower than many countries,

\footnotetext{
*Corresponding author: roman.fates@gmail.com
} 
even such as Chile, Romania, Bulgaria, etc. [2]. This situation does not correspond to the existing industrial, personnel, scientific and technological potential of Russia, and is probably related to systemic failures in the organization of scientific, technological and innovation activities at the present stage of development of the country.

\subsection{Analysis of the results of innovation support}

These days, there is a system of state funds and development institutions in Russia, which provides direct support for research and development stage and at subsequent stages of implementation and production with the help of financial instruments that have proven themselves in other countries. Among these tools are grants, loans, deposit of funds and property in the authorized capital, bank loans, subsidies to compensate part of the cost of paying interest on loans of small innovative companies, government procurement, subsidies to compensate for the development of new products, services and methods production and new production processes. However, the results leave much to be desired. According to Rosstat, the cumulative GDP share of high-tech industries is less than 1\% [1]. If we talk about the proportion of organizations engaged in innovation in industry, this figure will be in the region of $7.3 \%$. At the same time, in European countries such as Germany, Finland, and the Baltic countries, this figure will vary from 30 to 50 percent [2].

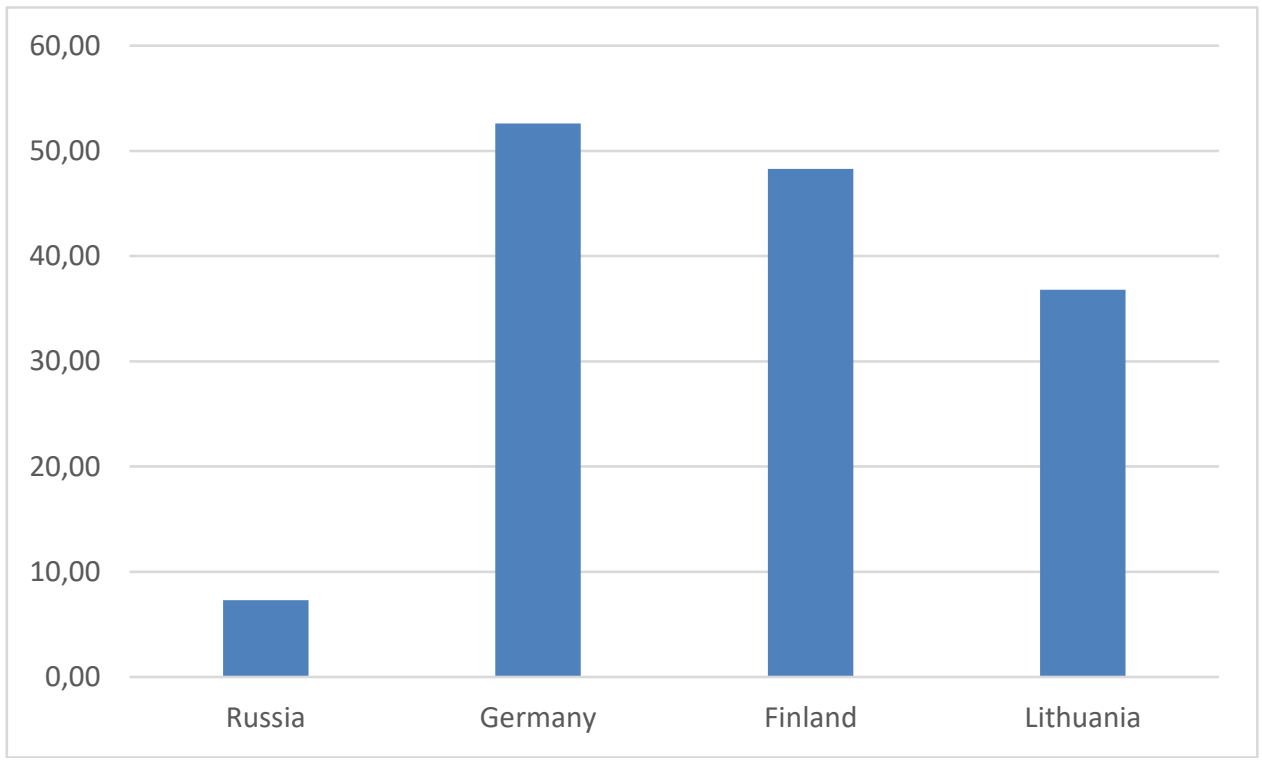

Fig. 1. The proportion of organizations that implement innovations in industry.

The situation on statistics of patent commercialization does not look good. Between 1993 and 2004, their share grew, reaching a maximum of 7.66\% in 2004. After this period, a steady decline began, and in 2012 this figure dropped to $0.14 \%$ [3]. In the period from 2013 to 2017 , the total number of commercialized projects never exceeded $2 \%$. 


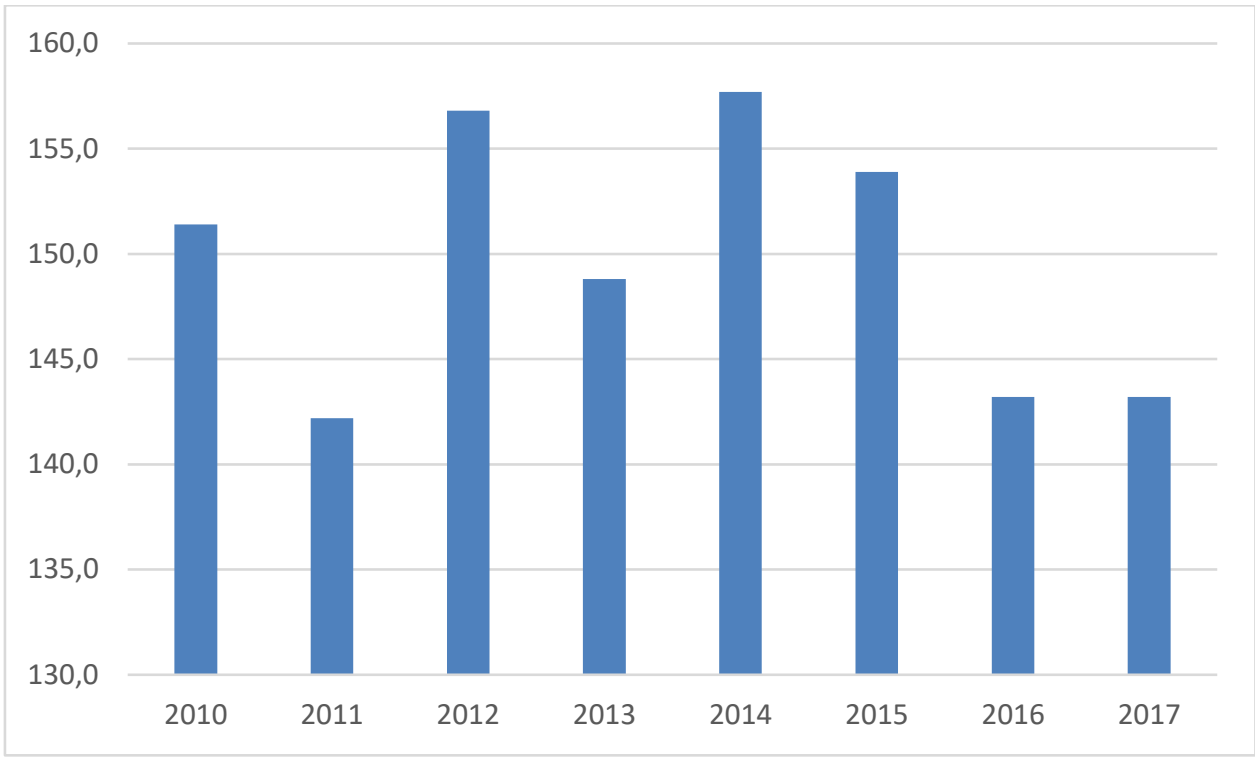

Fig. 2. The number of patents for inventions granted by Rospatent to Russian applicants per 1 million people.

\section{The problem of definition}

Based on these data, it can be concluded that the Russian system is uncomfortable for most enterprises. According to RID data, no more than $10 \%$ of the patentable results of intellectual activity receive a patent, and only slightly more than $2 \%$ are commercialized. The number of intangible assets of domestic enterprises on average is no more than 0.3 $0.5 \%$ of the value of non-current assets. The indicator of intangible assets of foreign enterprises in economically developed countries reaches $30 \%$ [2]

The economic development of the Russian economy depends on the following factors: levels of scientific, innovative and technological potentials; the state of managerial, labor, information and financial resources; development of scientific, material and technical, educational technologies and many other minor factors.

Creating an innovation support system is a promising area, most innovative projects are created with the support of federal programs and funds, as well as in federal organizations and are supported by local authorities.

As of the end of 2016 [1], the territorial distribution of organizations performing R \& D turned out to be as follows: about $80 \%$ of organizations are located in 32 regions of the Russian Federation, a third of which are concentrated in the Moscow Region, Moscow and St. Petersburg [5].

The concept of long-term socio-economic development of the Russian Federation for the period up to 2020 defines the formation of new centers of socio-economic development as the main direction for the development of an innovative economy by creating a network of territorial production clusters. Given the above, it can be concluded that the development of clusters in the North-West region is extremely promising. 


\section{The Logic of Creating International Consortia}

Most cluster initiatives are implemented on the basis of the work of professional management structures. Cluster initiatives for the successful implementation of goals should organize and carry out various activities that are not only aimed at creating a strong team among "their" cluster members, but also at developing and promoting a consortium. The actual creation of international consortia to fully meet the needs of cluster members, as well as the creation of international relations and strategic alliances with other international cluster associations, including with the aim of attracting additional financial flows from other, possibly international sources. As a form of association, the consortium, unlike the cluster, is not tied to a specific territory, but only implies a form of joint implementation of projects.

\subsection{Practical experience}

As an example of such an association, the St. Petersburg Cluster of Clean Technologies for the Urban Environment can serve as an international consortium.

In 2014, an international consortium "St. Petersburg Clean Technologies Cluster for the Urban Environment" was established in St. Petersburg. To date, members of the consortium are representatives of Finland, North, Central and Latin America, Denmark, Norway, Japan and Russia. The Cluster includes more than 38 enterprises and organizations, including: the St. Petersburg Non-Formal Education Cluster for Sustainable Development, the TerritorialIndustry Cluster Agropolis "Alkiagrobioprom" of the Republic of Tatarstan and the St. Petersburg Innovation-Technology Cluster of Energy Saving in Housing and Public Utilities and Industry.

The St. Petersburg Cleantech Cluster for the Urban Environment (hereinafter referred to as the Cluster) is a member of the Global Cleantech Cluster Association (GCCA), which unites more than 50 national clusters that represent more than 10,000 cleantech companies worldwide.

Also, the Cluster has signed an agreement on joining BALTIC CLEANTECH ALLIANCE (BCA), which is formed as a "mega-cluster and created using a cluster approach based on cooperation between already existing clusters of the Baltic Sea region. The Alliance has been created and is developing as part of the CB2East project, which is funded under the INTERREG program in the central part of the Baltic Sea region.

This form of the cluster allows for sustainable interaction of cluster members located in the territories of several countries engaged in the joint creation of goods or services participating in joint scientific, educational and commercial projects, which provides a synergistic effect in the development of the innovation economy of the member countries of cluster education and diffusion innovation between the two [9].

According to the Northwest Federal District Development Strategy and the European Union Strategy for the Baltic Sea Region up to 2020, the promotion of innovative platforms and support of clean green technology clusters are crucial for the process of economic modernization when implementing a long-term public policy transition to a sustainable economy. The cluster promotes the development of business cooperation to solve the problem of promoting innovative platforms and supporting clean "green" technologies in the field of entrepreneurship.

An example of such cooperation can be projects already implemented by the Cluster, such as "Effective Light", "Warm City" and many others.

In the framework of the "Effective Light" project, energy efficient repairs of general building lighting were carried out with the use of presence sensors and LED lamps of domestic production in 3,500 apartment buildings in St. Petersburg, which is $15 \%$ of the 
total housing stock of St. Petersburg for a total of 300 million rubles. Also, proposals were made to amend legal acts to reduce barriers to the widespread adoption of LED lighting. The project is a precedent with the prospect of a complete abandonment of the use of lowefficiency light sources in the illumination of urban infrastructure in St. Petersburg [7].

The project "Warm City" was one of the first in Russia to combine the Norwegian, Danish companies and Russian manufacturers of energy-saving equipment and services to improve energy efficiency into a transnational industrial chain.

For the third year in a row, cluster projects in the field of improving the energy efficiency of the urban environment of the St. Petersburg Clean Technologies Cluster for the Urban Environment are the winners of the regional stage and the finalists of the AllRussian competition of implemented projects in the field of energy saving and energy efficiency ENES [7].

The cluster is actively developing in the direction of science and education. A good example of such cooperation is the joint project of the ENPI Southeast Finland and Russia Neighborhood and Cooperation Program. Project 2011-091-SE693 "Efficient Energy Management - EFEM" ("Energy Efficient Management"). In this project, a functional chain consisting of the links "science - production-market" was clearly traced. The project participants included educational institutions - Lappeenranta University of Technology (LUT), St. Petersburg University of Peter the Great, and representatives of business and government agencies. The project resulted in combining the best practices, business models and tools from Finland and Russia for the development of energy efficiency in the housing sector [4].

Cluster members participate in the development of international cooperation in the field of education in close cooperation with northern countries. At the moment, the project of the Nordic countries and Russia "Business and value added in the Arctic: an interdisciplinary perspective." The aim of the project is to study the prospects for cooperation between the Nordic countries and Russia and to promote the development of knowledge on the development of the Arctic based on an interdisciplinary approach.

Following the recommendations of the Ministry of Economic Development of Russia together with the Ministry of Industry and Trade of Russia and interested federal and regional executive authorities, the Cluster initiated the creation of the «Green Clusters of Russia consortium».

The Green Clusters of Russia Consortium is a Cluster Association that promotes cooperation of actions to achieve the common goals of the participants by creating effective mechanisms for interaction between business and government, educational and scientific institutions, including on the principles of international and cross-border cooperation and public-private partnership [8].

The main objective of the Cluster Association is the organization and implementation of effective and mutually beneficial joint programs, cluster initiatives and intercluster projects in the field of clean technologies, "green technologies", where one of the main priorities of the activity is environmental protection and recycling, as a direction of the process of economic modernization and factors of a long-term state policy of transition to a "green economy" [7].

\section{Conclusion}

Summarizing the above, it can be determined that the activities of the international consortium "St. Petersburg Cluster of Clean Technologies for the Urban Environment" contribute to the implementation of complex projects and innovative solutions for the introduction and development of promising technologies in St. Petersburg and other regions of the Russian Federation, the formation of cooperation between the business and 
professional international community in the field of creating an innovative environment uniting various players in such popular areas as ecology and energy efficiency that promotes the development of innovative development of the economy not only in Russia but also in other countries.

\section{References}

1. http://www.gks.ru/wps/wcm/connect/rosstat_main/rosstat/en/figures/industry/

2. N.V. Gorodnikova, L.M. Gokhberg, K.A. Ditkovsky, Indicators of innovation, 2018: statistical compilation National Research University "Higher School of Economics" (HSE, Moscow, 2018)

3. https://repository.jmls.edu/cgi/viewcontent.cgi?article=1364\&context=ripl

4. I.V. Skvortsova, Y.R. Nurulin, Scientific and technical statements of the SPbSTU, Economic Sciences 2(240), 51-59 (2016)

5. I.V. Bitkina, Almanac "Science. Innovation. Education" 15, 174-182 (2014)

6. http://www1.fips.ru/wps/wcm/connect/content_en/en/main

7. http://spbcleantechcluster.nethouse.ru/

8. I.V. Skvortsova, V.M. Makarov, Scientific and technical statements SPbSTU, Economic Sciences 2-185, 173-178 (2013)

9. I.V. Skvortsova, Y.R. Nurulin, MATEC Web of Conferences 170, 01004 (2018) 